\title{
Empirical analysis of the impact of Hong Kong's offshore trade on its economic growth
}

\author{
Qunhua Yuan \\ School of Economic and Trade, Guangdong University of Foreign \\ Studies, China \\ yqb15@126.com
}

\author{
Xiaoru Zhang \\ School of Mathematics and Statistics, Hubei University, \\ China \\ zxr5260@163com
}

Abstract. As the rapid development of offshore trade has become an important pillar of Hong Kong's economy, analyzing the economic growth effect of Hong Kong's offshore trade is of great significance. This paper analyzes the impact of offshore trade on Hong Kong's economic growth during the period of 2002 to 2017 on the basis of a review of the research on the development of offshore trade in Hong Kong and the study of the economic growth effects of trade in the perspective of its particularity. Based on the theoretical analysis, this paper then empirically examines the economic growth effect of Hong Kong's offshore trade and concludes that offshore trade has promoted Hong Kong's economic growth, thus becoming an important factor of growth. Finally, it proposes policy recommendations for developing offshore trade to promote Hong Kong's economic growth: attract multinational corporations to set up headquarters or offices in Hong Kong, strengthen Hong Kong's economic ties with mainland China, and accelerate the development of RMB offshore financial markets in Hong Kong. From a global perspective, Hong Kong, as a bridge linking the regional and global economies has not only promoted the optimal allocation of factors of production and resources in the region, but also enhanced the facilitation of foreign trade and international competitiveness.

Keywords: Hong Kong, offshore trade, economic growth.

JEL Classification: F10, F13, O24 


\section{INTRODUCTION}

Since the 1990s, as economic globalization and regional division of labor have been moving forward, and multinational corporations have allocated resources globally, and especially with the rapid development of information and network technologies, offshore trade started actively growing on the basis of transit trade. London, New York, Tokyo, Singapore and Hong Kong, today's major international trade centers and the global offshore trading centers, have in such a way achieved control over trade. In the same period, due to its high wage costs and the rapid development of port facilities in the mainland China, Hong Kong's transit trade has gradually been replaced by offshore trade. Especially after entering the new century, the accelerated offshore trade has become one of the main trade modes in Hong Kong. Therefore, exploring the economic growth effect of offshore trade in Hong Kong has both theoretical and practical significance. Its theoretical significance lies in the particularity of offshore trade as such. Unlike ordinary import and export trade, the flow of goods, business flows and capital flows in offshore trade are separate. Its practical significance is that analyzing the economic growth effect of Hong Kong's offshore trade is crucial for understanding of the current economic situation and future development prospects of Hong Kong, as well as for providing reference for the development of offshore trade to other important domestic international trade centers, such as Shanghai and Guangzhou

Therefore, this paper firstly introduces the research on the development of offshore trade in Hong Kong and its economic growth effect. Then analyse the mechanism of offshore trade. The third and is descriptive and empirical analysis of Hong Kong offshore trade and economic growth. Lastly, this paper draws conclusions and make some policy suggestions.

\section{LITERATURE REVIEW}

\subsection{Research on the development of offshore trade in Hong Kong}

There are few studies on the development of offshore trade in Hong Kong, and the existing literature mainly focuses on the relationship about offshore trade between Hong Kong and economic growth in mainland China. Shen et al. (2013) believed that the rapid growth of offshore trade in Hong Kong is inseparable from the rise of China's economy. During 2002 to 2011, the average value of goods sold by mainland China and to mainland China were $38 \%$ and $57 \%$, and the deepening of international division of labor in the trading field, the dynamic changes in Hong Kong's factor endowments, and the rise of China's economy are the reasons for the rapid development of offshore trade in Hong Kong. Peng et al. (2013) calculated and proved that Hong Kong's offshore trade has a significant role in promoting the industrial development of the Pearl River Delta region. Niu (2014) analyzed the key factors in the development of offshore trading centers with the main offshore trading centers Hong Kong, Singapore and Tokyo as samples. The empirical analysis of Yuan (2019) showed that the regional headquarters of multinational corporations have a significant role in promoting the development of offshore trade in Hong Kong.

These researches mainly focus on the relationship between the development of offshore trade in Hong Kong and the economic and trade relations in mainland China, but less on the economic growth effects from the perspective of offshore trade in Hong Kong. 


\subsection{Research on the economic growth effect of trade}

The research on the economic growth effects of trade is very rich, and some documents using econometric analysis methods are listed here. $\mathrm{Li}$ (2009) used Granger causality test and regression analysis to verify the economic growth contribution of Hong Kong's transit trade from 1964 to 2007, and concluded that transit trade has a strong impetus to Hong Kong's economy. The empirical research results of Yang et al. (2010) showed that the export of service trade promotes the growth of Hong Kong's economy, and the effect of imports on economic growth is not obvious. Huang and Shi (2018) used the vector autoregressive model (GVAR) to measure the contribution of regional trade and FDI to economic growth in the "Belt and Road" region. They concluded that the impact of China's international trade and foreign investment on China's economic growth is significantly greater than that of other regions, and the impact of China's outbound investment is greater than the impact of international trade on the local economy. Wang (2018) constructed a new structural economics theoretical model with two big countries. The conclusion is that industrial upgrading and macroeconomic growth are endogenous and synchronous, and the impact of the acceleration of trade liberalization on macro output growth and industrial dynamics are not monotonous. Gao et al (2019) concluded that the role of exports in promoting China's economic growth during the transition period is mainly due to the technology spillover effect of the export sector on the non-export sector, rather than its relative factor productivity. Many foreign scholars have also carried out a lot of research on this topic. Jacob W. Musila and Zelealem Yiheyis (2015) examined the impact of trade openness on the level of investment and the rate of economic growth for Kenya. Mohammad MafizurRahman(2021) found that the effects of energy consumption, international trade, capital and FDI are found to be positive and significant on the economic growth of BRICS and ASEAN countries. Oloyede Betsy M ect.(2021) found a positive but insignificant nexus between economic growth rate and trade openness in both the combined simulated ECOWAS and SADC and the individual REC.

The above research mainly discusses the economic growth effect of common import and export trade and provide certain reference, especially the contribution of economic growth of transit trade is more reference value. However, since they are not specifically for offshore trade research, they do not proceed from the particularity of offshore trade, nor do they explore the mechanism by which offshore trade affects economic growth.

Although the development of offshore trade has been relatively rapid in recent years, there is still relatively little research on this subject, and few countries or regions publish data on offshore trade. Therefore, this paper will analyse the economic growth effects and explore the mechanism effect from the perspective of offshore trade in Hong Kong based on the data during the period of 2002 to 2017.

\section{METHODOLOGY}

In order to verify the effect of Hong Kong's offshore trade on regional economic growth, this paper $\mathrm{x}$ uses a linear regression model to regression the offshore trade and GDP during the period of 1998 to 2017. And linear regression model is adopted:

$$
G D P=a+\beta * O T+e,
$$

the offshore trade volume is abbreviated as OT.

The data comes from the website of the Statistics Department of the Hong Kong SAR Government. The italic data is supplemented by the average increment of the data according to the existing year. Descriptive statistics of each variable are shown in the following table. 
Descriptive statistics of variable

\begin{tabular}{|l|c|c|c|c|c|}
\hline \multicolumn{1}{|c|}{ Variable } & Obs & Mean & Std. Dev. & Min & Max \\
\hline year & 30 & 2002.5 & 8.803 & 1988 & 2017 \\
\hline offshoretrade & 30 & 21821.8 & 16476.497 & 1377 & 52302 \\
\hline gdp & 30 & 14383.6 & 5804.637 & 5493 & 26610 \\
\hline
\end{tabular}

Source: own calculation.

\section{EMPIRICAL RESULTS AND DISCUSSION}

\subsection{The analysis of the impact mechanism of offshore trade on economic growth}

\subsubsection{Analysis of the impact of trade on economic growth}

National economic statistics show that net export trade is part of demand. Keynesianism believes that demand drives economic growth, so that trade drives economic growth in the form of demand. The mechanism of action is that export trade is a foreign demand for domestic products, which will promote the production of domestic exports, and the production factors will receive corresponding compensation, thereby promoting economic growth. In this process, as export trade leads to the inflow of production factors from other countries into the country, these factors of production will be combined with domestic production factors to obtain remuneration, increasing the income of the exporting countries of production factors and the countries producing goods. Import trade, especially equipment imports, will also promote economic growth by increasing domestic production technology and productivity. Another reason for international trade to promote economic growth is to increase competition among enterprises. The result of trade is the survival of the fittest in the market and the elimination of inefficient enterprises, whichpromote to the overall benefits of the society.

\subsubsection{Analysis of the impact mechanism of offshore trade on Hong Kong's economic growth}

Because of its particularity, the flow of goods, business flows and capital flows of offshore trade are separate. Although the flow of goods generally does not bring the charges such as loading and unloading costs to the local, the flow of funds and business processing of offshore trade the gross profit/commissions, trade financing and insurance, logistics and other related expenses will still bring local income. According to the census and statistics department of the Hong Kong SAR Government, the gross profit/commission from offshore trading of goods refers to the gross profit earned from "turnover trading activities" and the commission earned from "goods and services related to offshore trading", and there is no value of the goods involved. In fact, offshore trade gross profit/ commission accounting for about $10 \%$ of Hong Kong residents' income, is one of the important sources of Hong Kong's economic growth. In addition, although other relevant trade finance, insurance, logistics are not exactly calculated, the benefits of offshore trade will promote the development of modern service industry, increase employment in management, marketing and technology-related industries, and promote the transformation and transformation of Hong Kong's trade. 


\subsection{Descriptive statistics analysis of the development of offshore trade in Hong Kong}

\subsubsection{Overview of the development of offshore trade in Hong Kong}

Since the 1990s, with the rapid rise of labor costs in Hong Kong and the gradual improvement of the port infrastructure and the improvement of trade facilitation in mainland China, Hong Kong's offshore trade has developed rapidly on the basis off transit trade. It increased from 137.7 billion Hong Kong dollars in 1988 to 445.58 billion Hong Kong dollars in 2017, an increase of 32.36 times, with an average annual growth of $12.74 \%$, faster than the average annual growth of $9.55 \%$ in the same period. In 2006 , Hong Kong's offshore trade exceeded transit trade for the first time and has maintained this trend ever since. The proportion of offshore trade in Hong Kong's GDP increased from 25.07\% in 1988 to $167.45 \%$ in 2017, with the highest proportion in 2013 reaching $231.70 \%$ (table 1). It can be seen that offshore trade plays a decisive role in Hong Kong's economic growth.

Table 2

Comparison of Hong Kong Re-export Trade and Offshore Trade Development Unit: HK\$100 million (calculated by present value)

\begin{tabular}{|l|c|c|c|c|c|c|c|}
\hline Year & $\begin{array}{c}\text { Transit } \\
\text { trade } \\
\text { volume }\end{array}$ & $\begin{array}{c}\text { Offshore } \\
\text { trade volume }\end{array}$ & GDP & Year & $\begin{array}{c}\text { Transit trade } \\
\text { volume }\end{array}$ & $\begin{array}{c}\text { Offshore } \\
\text { trade } \\
\text { volume }\end{array}$ & GDP \\
\hline 1988 & 2754 & 1377 & 5493 & 2003 & 16207 & 16666 & 12348 \\
\hline 1989 & 3464 & 2239 & 5634 & 2004 & 18931 & 18358 & 12919 \\
\hline 1990 & 4140 & 3101 & 5825 & 2005 & 21141 & 20872 & 13830 \\
\hline 1991 & 5348 & 3963 & 6685 & 2006 & 23265 & 23465 & 15034 \\
\hline 1992 & 6908 & 4825 & 7793 & 2007 & 25784 & 26589 & 16508 \\
\hline 1993 & 8232 & 5687 & 8975 & 2008 & 27334 & 33628 & 17075 \\
\hline 1994 & 9479 & 6550 & 10126 & 2009 & 24113 & 29312 & 16592 \\
\hline 1995 & 11125 & 7873 & 11055 & 2010 & 29615 & 38863 & 17777 \\
\hline 1996 & 11858 & 9196 & 11919 & 2011 & 32716 & 44670 & 19344 \\
\hline 1997 & 12445 & 10520 & 13239 & 2012 & 33755 & 46690 & 20371 \\
\hline 1998 & 11592 & 11763 & 12668 & 2013 & 35053 & 49544 & 21383 \\
\hline 1999 & 11784 & 13006 & 12109 & 2014 & 36175 & 52302 & 22600 \\
\hline 2000 & 13917 & 14250 & 13445 & 2015 & 35584 & 43349 & 23983 \\
\hline 2001 & 13275 & 14416 & 12799 & 2016 & 35454 & 42439 & 24908 \\
\hline 2002 & 14296 & 14583 & 12461 & 2017 & 38759 & 44558 & 26610 \\
\hline
\end{tabular}

Source: own calculation.

\subsubsection{The gross profit and commission paid by the offshore trade in goods accounted for the proportion of residents' income}

From the gross profit/official commission earned from the offshore trade in goods, the total gross profit margin of offshore trade increased from HK\$103.04 billion in 2002 to HK\$293.859 billion in 2017, a 2.85 times increase and an average annual increase of $5.80 \%$. The proportion of offshore trade gross profit/commissions to local residents' income increased from $7.89 \%$ in 2002 to $13.17 \%$ in 2012, and then dropped to $10.60 \%$ in 2017 . The gross profit obtained from the transfer of trade activities accounted for more than $85 \%$ since 2002 , and increased every year, reaching $88.74 \%$ in 2017. 
Hong Kong offshore trade gross profit and commission accounted for the proportion of local residents' income

\begin{tabular}{|c|c|c|c|c|c|c|}
\hline Year & $\begin{array}{c}\text { Turnover } \\
\text { margin } \\
\text { (HK\$100 } \\
\text { million) }\end{array}$ & $\begin{array}{c}\text { Commission on } \\
\text { goods and } \\
\text { services related } \\
\text { to offshore } \\
\text { transactions } \\
\text { (HK \$100 } \\
\text { million) }\end{array}$ & $\begin{array}{c}\text { Account } \\
\text { (HK\$100 } \\
\text { million) }\end{array}$ & $\begin{array}{c}\text { Income of local } \\
\text { residents (HK } \\
\$ 100 \text { million) }\end{array}$ & $\begin{array}{c}\text { The proportion } \\
\text { of local } \\
\text { residents' } \\
\text { income (\%) }\end{array}$ & $\begin{array}{c}\text { The proportion of } \\
\text { gross profit of } \\
\text { turnover trade to the } \\
\text { proportion of } \\
\text { earnings from } \\
\text { offshore trade (\%) }\end{array}$ \\
\hline 2002 & 883.20 & 146.85 & 1030.04 & 13057.31 & 7.89 & 85.74 \\
\hline 2003 & 1001.36 & 163.69 & 1165.06 & 13640.14 & 8.54 & 85.95 \\
\hline 2004 & 1134.73 & 187.27 & 1322.00 & 14222.98 & 9.29 & 85.83 \\
\hline 2005 & 1285.47 & 204.53 & 1490.00 & 14805.81 & 10.06 & 86.27 \\
\hline 2006 & 1434.95 & 222.55 & 1657.49 & 15388.64 & 10.77 & 86.57 \\
\hline 2007 & 1613.26 & 246.33 & 1859.59 & 17035.67 & 10.92 & 86.75 \\
\hline 2008 & 1764.79 & 275.74 & 2040.53 & 18079.94 & 11.29 & 86.49 \\
\hline 2009 & 1714.91 & 251.11 & 1966.02 & 17090.07 & 11.50 & 87.23 \\
\hline 2010 & 2033.25 & 301.26 & 2334.51 & 18143.79 & 12.87 & 87.10 \\
\hline 2011 & 2304.62 & 312.98 & 2617.60 & 19889.09 & 13.16 & 88.04 \\
\hline 2012 & 2390.21 & 331.46 & 2721.67 & 20665.14 & 13.17 & 87.82 \\
\hline 2013 & 2459.45 & 323.66 & 2783.10 & 21788.24 & 12.77 & 88.37 \\
\hline 2014 & 2509.04 & 330.30 & 2839.34 & 23066.12 & 12.31 & 88.37 \\
\hline 2015 & 2434.07 & 321.00 & 2755.06 & 24426.56 & 11.28 & 88.35 \\
\hline 2016 & 2454.77 & 316.09 & 2770.86 & 25533.69 & 10.85 & 88.59 \\
\hline 2017 & 2607.70 & 330.89 & 2938.59 & 27717.17 & 10.60 & \\
\hline
\end{tabular}

Source: own calculation.

\subsubsection{The source structure of gross profits/commissions earned from offshore trade in Hong Kong}

The main sources of gross profit/commission earned from offshore trade in Hong Kong are the United States, mainland China, the United Kingdom, Germany and Japan, accounting for over 65\% since 2002 and over $70 \%$ in most years.

Among them, the gross profit/commission earned by offshore trade from the United States increased continuously, from HK $\$ 27.53$ billion in 2002 to HK $\$ 101.945$ billion in 2017, accounting for $26.7 \%$ to $34.7 \%$, making it the first source of gross profit/commission for offshore trade in Hong Kong. However, the gross profit/commission amount earned by offshore trade from mainland China increased from HK $\$ 34.192$ billion in 2002 to HK $\$ 60.205$ billion in 2017 , but the proportion decreased from 33.2 percent to 20.5 percent, indicating that the profit margin of offshore trade between mainland China and Hong Kong is decreasing. The gross profit/commission ratio of other offshore trade from the United Kingdom and Germany changed similarly, from around 4\% to around 6\%. Gross margin/commission earned from offshore trade from Japan also fell from $7.8 \%$ to $4.5 \%$. 
Source structure of Hong Kong offshore gross profit/commission

\begin{tabular}{|c|c|c|c|c|c|c|}
\hline Year & $\begin{array}{c}\text { United States } \\
(\%)\end{array}$ & $\begin{array}{c}\text { Mainland China } \\
(\%)\end{array}$ & $\begin{array}{c}\text { Kingdom United } \\
(\%)\end{array}$ & $\begin{array}{c}\text { Germany } \\
(\%)\end{array}$ & $\begin{array}{c}\text { Japan } \\
(\%)\end{array}$ & $\begin{array}{c}\text { Account } \\
(\%)\end{array}$ \\
\hline 2002 & 26.7 & 33.2 & 3.8 & 4.4 & 7.8 & 75.9 \\
\hline 2003 & 27.5 & 31.0 & 3.8 & 4.3 & 6.6 & 73.2 \\
\hline 2004 & 25.7 & 30.3 & 4.4 & 5.1 & 5.6 & 71.1 \\
\hline 2005 & 25.6 & 28.9 & 5.7 & 5.3 & 6.1 & 71.6 \\
\hline 2006 & 27.1 & 27.5 & 5.7 & 5.3 & 5.8 & 71.4 \\
\hline 2007 & 26.4 & 26.3 & 5.7 & 5.6 & 5.6 & 69.6 \\
\hline 2008 & 26.3 & 24.7 & 6.3 & 6.1 & 5.0 & 68.4 \\
\hline 2009 & 28.0 & 21.1 & 6.2 & 5.2 & 5.3 & 65.8 \\
\hline 2010 & 30.0 & 21.4 & 6.8 & 5.2 & 4.9 & 68.3 \\
\hline 2011 & 31.3 & 20.4 & 5.7 & 5.2 & 4.7 & 67.3 \\
\hline 2012 & 32.9 & 19.9 & 6.1 & 5.1 & 4.7 & 68.7 \\
\hline 2013 & 32.6 & 20.5 & 6.3 & 6.1 & 4.8 & 70.3 \\
\hline 2014 & 33.0 & 20.7 & 6.6 & 6.3 & 4.1 & 70.7 \\
\hline 2015 & 34.3 & 20.5 & 6.7 & 6.2 & 4.0 & 71.7 \\
\hline 2016 & 35.2 & 19.8 & 6.6 & 6.2 & 4.3 & 72.1 \\
\hline 2017 & 34.7 & 20.5 & 6.1 & 6.3 & 4.5 & 72.1 \\
\hline
\end{tabular}

Source: own calculation.

\subsection{Empirical analysis of Hong Kong offshore trade and economic growth}

\subsubsection{Model establishment and regression analysis}

According to the data of Hong Kong offshore trade volume and GDP, a broken line graph (Figure 1) shows that the correlation between the growth of Hong Kong offshore trade and GDP growth is close to a linear relationship.

1988-2017 Hong Kong offshore trade and gross domestic product data HK $\$ 100$ million (in present value).

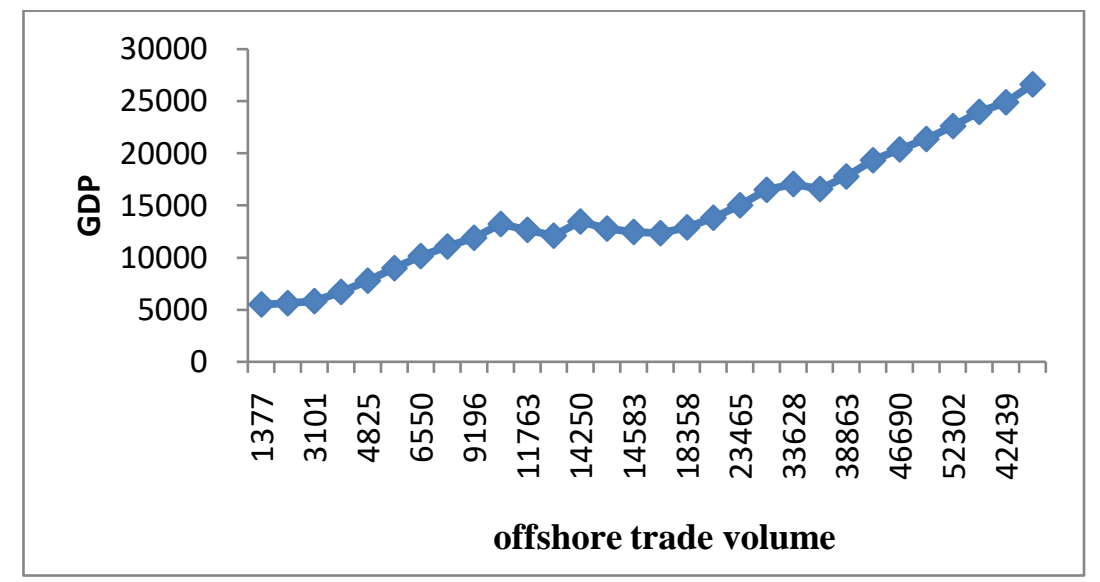

Figure 1. The simulated broken line diagram of the relationship between Hong Kong offshore trade and GDPunit: HK \$100 million

Source: own calculation. 
From the overall P-value (5.55E-15), it passes the test. The E-G test shows that the time series of offshore trade and GDP in Hong Kong are all one-order integrated series, which conforms to the premise of co-integration of time series (table 4). The residual test result is a stationary series, so there is a cointegration relationship between the time series of Hong Kong offshore trade and the time series of GDP (table 5). OT coefficient indicates that for every unit of offshore trade increase, economic grows 0.3325 units.

Table 5

Stability test results of Hong Kong offshore trade OT and GDP

\begin{tabular}{|l|c|c|c|c|c|}
\hline variable & $(\mathbf{C}, \mathbf{T}, \mathbf{K})$ & ADF value & $\begin{array}{c}\mathbf{5 \%} \text { critical } \\
\text { value }\end{array}$ & $\mathbf{1 \%}$ critical value & conclusion \\
\hline GDP & $(\mathrm{C}, \mathrm{T}, 0)$ & -0.3036 & -3.5742 & -4.3098 & non-stationary \\
\hline $\mathrm{OT}$ & $(\mathrm{C}, \mathrm{T}, 0)$ & -1.9453 & -3.5742 & -4.3098 & non-stationary \\
\hline$\triangle \mathrm{GDP}$ & $(\mathrm{C}, \mathrm{T}, 0)$ & -3.7562 & -3.5806 & -4.3240 & stationary \\
\hline$\triangle \mathrm{OT}$ & $(\mathrm{C}, \mathrm{T}, 0)$ & -5.2509 & -3.5806 & -4.3240 & stationary \\
\hline
\end{tabular}

Note: the test form $(\mathrm{C}, \mathrm{T}, \mathrm{K})$ respectively represents the order of the unit root test equation including constant term, time trend term and lag term.

Source: own calculation.

Table 6

Unit root test results of equation residuals

\begin{tabular}{|c|c|c|c|c|c|}
\hline variable & $(\mathrm{C}, \mathrm{T}, \mathrm{K})$ & ADFvalue & $\begin{array}{c}5 \% \text { critical } \\
\text { value }\end{array}$ & $1 \%$ critical value & conclusion \\
\hline$\varepsilon$ & $(\mathrm{C}, 0,0)$ & -5.1259 & -2.9763 & -3.6999 & stationary \\
\hline
\end{tabular}

Source: own calculation.

\section{(2) Granger causality test of Hong Kong offshore trade and economic growth}

In order to verify whether there is a causal relationship between Hong Kong offshore trade and economic growth, this paper adopts the granger causality test method to test the above two variables. According to the results of three-order lag (table 7), when Hong Kong's Offshore Trade is at a significant level of 6.77\%, "OT (Offshore Trade) is not granger's reason for GDP" is rejected. Therefore, Hong Kong's Offshore Trade is the cause of its economic growth. When Hong Kong's GDP is at a significant level of $85.22 \%$, "GDP is not granger's reason for OT (Offshore Trade)" is rejected, indicating that Hong Kong's economic growth (local GDP) is not the reason for the development of Offshore Trade. The conclusion is also consistent with the expectation that the development of offshore trade will promote the growth of local GDP. Due to the particularity of offshore trade, its development is related to the ability of the offshore trade center to handle international trade business, while not related to the development of local economy, which proves the local economy is not the reason for the development of offshore trade. 
Granger causality test results

\begin{tabular}{|l|c|c|c|}
\hline \multicolumn{1}{|c|}{ Null hypothesis: } & Sample & F-test & Probability \\
\hline GDP is not granger's reason for OT & 27 & 0.26154 & 0.8522 \\
\hline OT is not granger's reason for GDP & & 2.77959 & 0.0677 \\
\hline
\end{tabular}

Source: own calculation.

\section{CONCLUSION}

This paper analyzes the impact of offshore trade on Hong Kong's economic growth on the basis of a review of the research on the development of offshore trade in Hong Kong and the study of the economic growth effects of trade in the perspective of its particularity during the period of 2002 to 2017.Based on the above theoretical analysis, this paper used descriptive Statistics analysis and linear regression model to examine the economic growth effect of Hong Kong's offshore trade and concludes that offshore trade has promoted Hong Kong's economic growth, which is an important factor in Hong Kong's economic growth. Based on the above conclusions, this article puts forward the following policy recommendations for developing offshore trade in Hong Kong and promoting economic growth.

(1) Attracting multinational companies to set up headquarters or offices in Hong Kong

The offshore trade center is a commercial processing center. It should be considered to promote the development of offshore trade from the perspective of business linkages. First, there should be offshore trade demand between the two regions, that is, the starting point and the end point of the goods involved in offshore trade do not establish trade relations. If the starting point and the end point can be traded directly, then no offshore trade is needed. It can be seen that offshore trade have the tight commercial links between Hong Kong and other countries and regions. And the main body of commercial contacts are multinational corporations, which play an important role in international trade and international investment. Therefore, the important way for Hong Kong to develop offshore trade is attracting multinational corporations to set up their headquarters or offices in Hong Kong.

(2) Strengthening economic ties between Hong Kong and mainland China

Mainland China is the most important value market for Hong Kong's trade and business activities. Mainland China, the United States, Singapore, the United Kingdom, and Japan are the main markets (destinations) for the value of Hong Kong's current trade and business activities, separately accounting for $37.0 \%, 21.5 \%, 6.5 \%, 6.3 \%$, and $4.8 \%$, totally $76.1 \%$ in 2016 . Among them, the value of goods traded with mainland China was the largest, from 383.535 billion in 2002 to 140.383 billion in 2016, an average annual increase of $9.71 \%$ while the proportion showed a trend of increasing first and then decreasing, from 2002 $37.3 \%$ increased to $44.4 \%$ in 2010 and then fell to $37.0 \%$ in 2016. However, mainland China is not the main source of gross profit / commission earned by offshore trade in Hong Kong. For Hong Kong, gross profit/commission from offshore trade from mainland China has been growing, from HK $\$ 34.192$ billion in 2002 to HK $\$ 60.205$ billion in 2017, but its share has declined from $33.2 \%$ to $20.5 \%$. Therefore, with the strengthening of the mainland economy, the economic ties between Hong Kong and mainland China should be expanded to increase the proportion of gross profit and commission earned from the Mainland to the profits of offshore trade in Hong Kong. 
(3) Accelerating the development of RMB offshore financial market in Hong Kong

In view of the close relationship between Hong Kong's offshore trade and the mainland economy, the rapid development of the mainland economy will contribute further expand to Hong Kong's offshore trade, which accelerate the construction and improvement of the offshore financial market. On the one hand, if offshore trade between Hong Kong and mainland China can be settled in RMB, it will reduce the foreign exchange costs and risks of trade and promote the development of trade in goods in mainland China. On the other hand, Hong Kong has the unique advantages of developing the offshore financial market of the RMB: (1) Compared with London and Singapore, it has the advantage of "onecountry". The rapid development of offshore RMB market in Hong Kong is inseparable from the active support and promotion of national policies. (2) Compared with Shanghai and Shenzhen, it has the advantage of "two systems". Mainland China has not yet realized the free convertibility of capital under the capital account, and still has certain control measures on foreign exchange, but there are no such restrictions in Hong Kong. Therefore, there is an urgent need and conditions for the development of RMB offshore financial market in Hong Kong.

\section{ACKNOWLEDGEMENT}

We want to give our sincere gratitude to the editor and the anonymous referees for their useful comments and suggestions. This research is supported by Guangdong education science "13th five-year plan" research project $A$ study on the interaction between education openness and ideology in Guangdong (number: 2018 JKDY10).

\section{REFERENCES}

Gao, Y. D., \& Gong, M.Y. (2019). Spillover effect of export trade and economic growth in China during the transition period -- an empirical study based on spatial econometric model. International economic and trade exploration, 35(06),4-16.doi: 10.13687/j.cnki.gjjmts.2019.06.001

Hoekman, B., \& Braga, C. A. P. (1997). Protection and trade in services: a survey. Open Economies Review, 8(3), 285308. doi:10.1596/1813-9450-1747

Huang, X. D., \& Shi, R. R. (2018). Contribution of "One Belt And One Road" regional trade and FDI to economic growth -- a study based on GVAR model. Mathematical statistics and management, 37(03), 492-508. doi:10.13860/j.cnki.sltj.20180521-051

Li, J. J., \& Qiu, J. Y. (2017). Study on China's export potential to APEC members and its influencing factors - an empirical test based on the trade gravity model. Asia-pacific economy, 06, 5-13, doi:10.16407/j.cnki.10006052.2017.06.001

Li, L. (2009). Empirical analysis of contribution of Hong Kong entrepot trade to economic growth: 1964-2007. AsiaPacific Economy, 3, 114-117 .doi: 10.16407/j.cnki.1000-6052.2009.03.019

Liu, L., \& Zhang, G. (2008). Empirical analysis on the relationship between service trade and local economic growth in Hong Kong. Journal of Inner Mongolia agricultural university (social science edition), 10, 71-73. doi:10.16853/j.issn.1009-4458.2008.05.025

Musila, J. W., \& Yiheyis, Z. (2015). The impact of trade openness on growth: The case of Kenya. Journal of Policy Modeling, 37(2), 342-354. doi:10.1016/j.jpolmod.2014.12.001

Niu, K. (2014). Study on offshore trade. Master's thesis of jinan university, (5).

Oloyede, B. M., Osabuohien, E. S., \& Ejemeyovwi, J. O. (2021). Trade openness and economic growth in Africa's regional economic communities: empirical evidence from ECOWAS and SADC. Heliyon, 7(5), e06996. doi:10.1016/J.HELIYON.2021.E06996 
Peng, Y., \& Shen, K. H.. (2013). Study on the impact of Hong Kong offshore trade on the industrial development in the pearl river delta region -- an empirical analysis based on panel data of 48 districts and counties in the pearl river delta region. International economic and trade exploration, 29(02), 58-67, doi: 10.13687/j.cnki.gjjmts.2013.02.004

Rahman, M. M. (2021). The dynamic nexus of energy consumption, international trade and economic growth in BRICS and ASEAN countries: A panel causality test. Energy, 229, 120679. doi:10.1016/J.ENERGY.2021.120679

Shen, K. H., \& Peng, Y.( 2013). Offshore trade and the evolution of Hong Kong's status as an international trade center -- and the enlightenment to the construction of Shanghai international trade center. Asia-pacific economy, 03, 143-148. doi: 10.16407/j.cnki.1000-6052.2013.03.018

Tori, C. R., \& Tori, S. L. (2001). Exchange market pressure, trade, sovereign credit ratings, and US exports in banking services. Atlantic Economic Journal, 29(1), 48-62. doi:10.1007/BF02299931

Wang, Y. (2018). Industrial trends, international trade and economic growth. Economics (quarterly), 17(02), 753-780. doi:10.13821/j.cnki.ceq.2018.01.13

Xin, D. L., Zhang, Z. B., \& Cha W. H. (2016). Analysis of influencing factors of China's service trade export evidence from the micro enterprise level. International trade issues, 01, 71-81, doi:10.13510/j.cnki.jit.2016.01.007

Yang, F. M., \& Xiao, H. (2010). Study on the impact of service trade on economic growth in Hong Kong - an empirical analysis based on timing data from 1980 to 2009. International economic and trade exploration, 26(12), 3540, doi:10.13687/j.cnki.gjimts.2010.12.006

Yuan, Q. H. (2019). Analysis on the development status of offshore trade in Hong Kong and its influencing factors. Urban observation, $02,112-122$.

Zheng, D. Q., \& Yu, J. P. (2014). Study on micro-accounting and influencing factors of value-added value of China's export trade. International trade issues, 08, 3-13. doi:10.13510/j.cnki.jit.2014.08.001 